\title{
Diversity of the Polish isolates of Potato virus Y (PVY) from tomato
}

\author{
Zróżnicowanie polskich izolatów wirusa Y ziemniaka \\ (Potato virus Y, PVY) z pomidora
}

\author{
Beata Hasiów-Jaroszewska ${ }^{1}$, Julia Minicka ${ }^{1}$, Joanna Stachecka², Natasza Borodynko ${ }^{1}$, \\ Dorota Piękna-Paterczyk ${ }^{1}$, Henryk Pospieszny ${ }^{1}$
}

\section{Summary}

In 2012 and 2013 the presence of Potato virus $Y$ on tomato in greenhouses and fields was analyzed. A total number of 176 samples displaying different type of symptoms: deformation, discoloration, necrosis of leaves and growth retardation were collected. The presence of viral infection using enzyme-linked immunosorbent assay (ELISA) and transmission electron microscopy (TEM) was confirmed in 147 samples. Biological and genetic diversity of the virus isolates was also analyzed. The analyses revealed that the particular strains cause different symptoms on the tested plants such as Solanum lycopersicum cv. Moneymaker, S. melongena and Datura inoxia. In contrast to previous years, in which only isolates belonging to PVY Wi-P strains were observed, four different strains were identified: $P V Y^{N} W i-P, P V Y^{N} N 242, P V Y^{N T N}$ and $P V Y^{O}$. The isolates belonging to $P V Y^{N} W i-P$ strain remained dominant in the population.

Key words: PVY; Solanum lycopersicum; RT-PCR; identification; diversity

\section{Streszczenie}

W latach 2012 i 2013 przeprowadzono monitoring występowania wirusa Y ziemniaka na pomidorze. Pozyskano 176 prób z pomidora szklarniowego i gruntowego, charakteryzujących się różnymi objawami chorobowymi w postaci deformacji blaszek, przebarwień, nekroz liści oraz karłowacenia pędów. W 147 próbach potwierdzono obecność wirusa za pomocą testu immunoenzymatycznego oraz transmisyjnej mikroskopii elektronowej. Analizowano zróżnicowanie biologiczne i genetyczne pozyskanych izolatów. Wykazano, iż poszczególne szczepy mogą powodować odmienne objawy chorobowe na roślinach testowych: Solanum lycopersicum cv. Moneymaker, S. melongena oraz Datura inoxia. W przeciwieństwie do lat ubiegłych, w których obserwowano jedynie izolaty należące do szczepu PVY ${ }^{\mathrm{N} W i-P,}$ w badanym materiale zidentyfikowano cztery różne szczepy PVY: PVY ${ }^{\mathrm{N}}$ Wi-P, $P V Y^{N} N 242, P V Y^{N T N}$ i PVY . Izolaty należące do szczepu PVY ${ }^{N}$ Wi-P pozostały dominujące w populacji.

Słowa kluczowe: PVY; Solanum lycopersicum; RT-PCR; identyfikacja; zróżnicowanie

\footnotetext{
${ }^{1}$ Instytut Ochrony Roślin - Państwowy Instytut Badawczy

Zakład Wirusologii i Bakteriologii

Władysława Węgorka 20, 60-318 Poznań

B.Hasiow@iorpib.poznan.pl

${ }^{2}$ Uniwersytet Przyrodniczy w Poznaniu

Wydział Rolnictwa i Bioinżynierii

Wojska Polskiego 28, 60-637 Poznań
} 


\section{Wstęp / Introduction}

Wirus Y ziemniaka (Potato virus $Y$, PVY) należy do rodzaju Potyvirus, w rodzinie Potyviridae (Hall i wsp. 1998) i jest jednym $\mathrm{z}$ najgroźniejszych patogenów wirusowych porażających rośliny ziemniaka. Szacuje się, że ponad $40 \%$ bulw wczesnego ziemniaka w Polsce może być porażonych przez tego wirusa (Pospieszny i wsp. 2009). Wirus poraża również inne rośliny $z$ rodziny Solanaceae, jak: pomidor, tytoń czy paprykę (Aramburu i wsp. 2006; Loebenstein i Lecoq 2012). PVY jest przenoszony przez mszyce w sposób nietrwały, na kłujce owada. Początkowo przenoszony był głównie przez mszyce ziemniaczane (Myzus persicae, Aphis nasturtii i A. frangulae) (Harrington i wsp. 1986; Piron 1986), ale zmiany W strukturze populacji mszyc żerujących na ziemniaku oraz okresie ich żerowania spowodowały, że obecnie PVY przenoszony jest również przez 20 innych gatunków mszyc, dla których ziemniak nie jest głównym żywicielem (Kostiw i Robak 2008). Wirus przenosi się także mechanicznie.

PVY powoduje zróżnicowane objawy chorobowe na porażanych roślinach, zależne od szczepu wirusa, warunków środowiska czy gatunku gospodarza (Tribodet i wsp. 2005). Na ziemniaku może wywoływać objawy - od mozaiki i przebarwień poprzez nekrotyczne plamy na liściach i bulwach, aż po karłowacenie roślin i opadanie liści, co znacząco wpływa na pogorszenie jakości plonów (Beczner i wsp. 1984). Podobnie w przypadku pomidora objawy powodowane przez tego wirusa mogą być zróżnicowane: od łagodnej mozaiki, poprzez przewężanie i wydłużanie pędów oraz blaszek liściowych, deformacje, zahamowanie wzrostu czy nierównomierne wybarwianie się owoców.

Materiał genetyczny wirusa stanowi pojedyncza, sensowna nić RNA o długości około 9700 nukleotydów. $\mathrm{Na}$ końcu 5' związane jest białko $\mathrm{VPg}$, pełniące rolę w translacji oraz podczas syntezy RNA, natomiast na końcu 3' znajduje się ogon poliA. Genom wirusa zawiera jedną ramkę odczytu (ORF - open reading frame), a produktem translacji jest poliproteina, z której w wyniku cięcia trzema wirusowymi proteazami (P1-Pro, HC-Pro oraz NIa-Pro) powstaje dziesięć białek (P1-Pro, HC-Pro, P3, 6K1, Cl, 6K2, Vpg, NIa-Pro, NIb RdRp, CP). Ponadto, $\mathrm{W}$ wyniku zmiany ramki odczytu $\mathrm{w}$ cistronie $\mathrm{P} 3$ powstaje dodatkowe, jedenaste białko P3N-PIPO (Cuevas i wsp. 2012). Cząstki wirusa są nitkowate o długości około $730 \mathrm{~nm}$ i średnicy $11 \mathrm{~nm}$ (Dougherty i Carrington 1988). Dotychczas opisano występowanie trzech głównych szczepów wirusa $\left(\mathrm{PVY}^{\mathrm{O}}, \mathrm{PVY}^{\mathrm{N}}\right.$ i $\mathrm{PVY}^{\mathrm{C}}$ ) (Glais i wsp. 2002) oraz licznych rekombinantów. Spośród rekombinantów najliczniejszą grupę w Polsce stanowią izolaty należące do szczepów PVY ${ }^{\mathrm{N}} \mathrm{Wi}$ (Chrzanowska 1991) z dwoma podgrupami: PVY ${ }^{\mathrm{N}} \mathrm{Wi}-\mathrm{P}$ oraz $\mathrm{PVY}^{\mathrm{N}} \mathrm{N} 242$, a także izolaty należące do szczepu PVY ${ }^{\mathrm{NTN}}$.

Do 2000 roku PVY w Polsce występował sporadycznie na roślinach pomidora. Pierwsze masowe występowanie wirusa obserwowano w latach 2002 i 2008 na pomidorach szklarniowych w Wielkopolsce (Pospieszny 2003; Pospieszny i wsp. 2009). Obserwowano wówczas wyraźne objawy chorobowe przyczyniające się do znaczących strat w plonach. Wśród badanych izolatów na porażonych pomidorach odnotowano obecność jednego szczepu $\mathrm{PVY}^{\mathrm{N}} \mathrm{Wi}-\mathrm{P}$.

W roku 2012 ponownie zaobserwowano nasilenie występowania PVY na roślinach pomidora (Borodynko i Hasiów-Jaroszewska 2012). Jednak w przeciwieństwie do lat ubiegłych wirusa stwierdzono zarówno w uprawach pomidora szklarniowego, jak i gruntowego.

Celem pracy była charakterystyka biologiczna i genetyczna polskich izolatów wirusa pozyskanych z roślin pomidora.

\section{Materiały i metody / Materials and methods}

\section{Monitoring występowania wirusa $w$ uprawie pomidora i test biologiczny}

W latach 2012 i 2013 przeprowadzono monitoring występowania wirusa w uprawie pomidora szklarniowego i gruntowego. Próby pobierano w miesiącach letnich (lipiec/sierpień) w województwach: wielkopolskim, kujawsko-pomorskim, lubuskim, mazowieckim oraz dolnośląskim. Zebrano łącznie 176 prób (86 w roku 2012 oraz $90 \mathrm{w}$ roku 2013) z roślin pomidora $\mathrm{z}$ widocznymi objawami chorobowymi w postaci deformacji blaszek, przebarwień, nekroz liści oraz karłowaceniem pędów. Wszystkie pozyskane próby pasażowano na 14 gatunków roślin testowych $\mathrm{w}$ celu potwierdzenia obecności wirusa, określenia zakresu roślin gospodarzy oraz powodowanych symptomów. Zakres roślin testowych stanowiły: Capsicum annuum, Chenopodium quinoa, Datura inoxia, Nicotiana benthamiana, N. occidentalis, N. tabacum cv. Samsun, N. tabacum cv. White Burley, N. tabacum cv. Xanthi, Physalis floridana, Solanum lycopersicum cv. Beta Lux, S. lycopersicum cv. Grace, S. lycopersicum cv. Malinowy Ożarowski, S. lycopersicum cv. Moneymaker oraz S. melongena. Rośliny inokulowano mechanicznie zawiesiną wirusa $\mathrm{w}$ soku pochodzącym $\mathrm{z}$ zebranych prób pomidora roztartym w 0,05 M buforze fosforanowym ( $\mathrm{pH} 8,0) \mathrm{w}$ stosunku 1:1 (W/V) i utrzymywano w warunkach szklarniowych. Przez kolejne 3 tygodnie obserwowano objawy chorobowe, sugerujące wystąpienie infekcji wirusowej.

\section{Identyfikacja serologiczna wirusa}

Obecność wirusa we wszystkich roślinach testowych potwierdzono za pomocą testu serologicznego ELISA (enzyme-linked immunosorbent assay) (Clark i Adams 1977), z zastosowaniem komercyjnych przeciwciał i koniugatu przeciwko PVY (Bioreba). Do każdej studzienki nanoszono $100 \mu \mathrm{l}$ gamma-globuliny rozcieńczonej w buforze węglanowym i inkubowano przez 4 godziny w temperaturze $37^{\circ} \mathrm{C}$. Po inkubacji przeciwciała usuwano, a płytkę płukano trzykrotnie przez 3 minuty buforem PBS zawierającym 0,05\% Tween-20 (PBS-T), w objętości $200 \mu \mathrm{l}$ na każdą studzienkę. Fragmenty liści pochodzące $\mathrm{z}$ roślin testowych rozcierano $\mathrm{w}$ buforze ekstrakcyjnym w moździerzu i tak przygotowany sok roślinny nanoszono w objętości $100 \mu$ l do każdej studzienki. Dla każdej próbki wykonano dwa powtórzenia. Jako kontrolę negatywną 
nanoszono sok roślinny przygotowany ze zdrowych roślin. Płytkę inkubowano przez noc w temperaturze $4^{\circ} \mathrm{C}$. Po inkubacji płytkę płukano trzykrotnie w buforze PBS-T i do każdej studzienki dodawano $100 \mu \mathrm{l}$ gamma-globuliny sprzęgniętej $\mathrm{z}$ alkaliczną fosfatazą rozcieńczonej $\mathrm{w}$ buforze ekstrakcyjnym. Po czterech godzinach inkubacji w temperaturze $37^{\circ} \mathrm{C}$ płytkę płukano i wywoływano reakcję barwną stosując wywoływacz fosfatazy zawierający p-nitrofenylofosforan (Sigma-Aldrich) w objętości $1 \mathrm{mg} / \mathrm{ml}$. Pomiaru absorbancji dokonano za pomocą czytnika ELX800 (BioTek Instruments INC).

\section{Analiza w transmisyjnym mikroskopie elektronowym}

Wszystkie pozyskane próby pomidora ze szklarni i gruntu, jak również rośliny testowe wykazujące objawy chorobowe, były sprawdzane pod kątem obecności nitkowatych cząstek wirusowych o długości około $730 \mathrm{~nm}$ w transmisyjnym mikroskopie elektronowym (TEM, Hitachi 7700. Fragmenty blaszek liściowych o wielkości około $2 \times 2 \mathrm{~cm}$ rozcierano na szkiełku podstawowym w kilku kroplach wody destylowanej. Uzyskany sok roślinny nanoszono na siatki miedziane (Polysciences) pokryte warstwą formwaru i inkubowano 30 sekund. Warstwę soku odsączano za pomocą bibuły, nanoszono kroplę barwnika, odpowiednio $2 \%$ kwasu fosforowolframowego (PTA) o pH 7,2 lub $2 \%$ octanu uranylu (UA) o pH 7,2 (Sigma) i ponownie inkubowano. Obserwacje prowadzono w transmisyjnym mikroskopie elektronowym przy napięciu przyspieszającym $80 \mathrm{kV}$.

\section{Identyfikacja szczepów PVY techniką RT-PCR}

Całkowite RNA izolowano z fragmentów liści szczytowych wszystkich wstępnie zweryfikowanych roślin za pomocą kitu RNAeasy Plant Mini Kit (Qiagen) zgodnie $\mathrm{z}$ dołączona procedura. Dla każdej próby wykonano trzy odrębne reakcje RT-PCR (reverse transcription polymerase chain reaction) $\mathrm{z}$ trzema parami starterów (Rigotti i Gugerli 2007). Reakcje przeprowadzano przy użyciu zestawu DreamTaq PCR Master Mix (Thermo Scientific) w objętości $50 \mu \mathrm{l}$. Do każdej reakcji użyto $1 \mu \mathrm{l}$ odpowiedniego RNA o stężeniu $100 \mathrm{ng} / \mu \mathrm{l}, 200 \mathrm{nM}$ startera 5' i 3', $25 \mu \mathrm{l}$ 2x DreamTag PCR Master Mix oraz $1 \mu$ l RevertAid Reverse Transcriptase $(200 \mathrm{U} / \mu \mathrm{L})$ i $22 \mu \mathrm{l}$ wody. Najpierw przeprowadzono odwrotną transkrypcję przez 20 minut w temperaturze $42^{\circ} \mathrm{C}$, a następnie wstępną denaturację -3 minuty $\mathrm{w}$ temperaturze $95^{\circ} \mathrm{C}$. Amplifikację prowadzono w 30 cyklach obejmujących: denaturację: 45 sekund w temperaturze $94^{\circ} \mathrm{C}$, przyłączanie starterów: 45 sekund w temperaturze $57^{\circ} \mathrm{C}$ i wydłużanie nici: 60 sekund w temperaturze $72^{\circ} \mathrm{C}$. Reakcję zakończono w temperaturze $72^{\circ} \mathrm{C}$ przez 5 minut. Obecność otrzymanych produktów amplifikacji obserwowano na $1 \%$ żelu agarozowym w świetle UV. Na podstawie rozdziału elektroforetycznego produktów uzyskanych w wyniku reakcji RT-PCR uzyskane izolaty klasyfikowano do poszczególnych szczepów. Wielkość produktów RT-PCR powstających w reakcji dla każdego ze szczepów zamieszczono w tabeli 1.
Tabela 1. Identyfikacja szczepów PVY za pomocą reakcji RT-PCR (Rigotti i Gugerli 2007)

Table 1. Identification of PVY strains using RT-PCR reaction (Rigotti and Gugerli 2007)

\begin{tabular}{l|c|c|c}
\hline \multirow{2}{*}{$\begin{array}{c}\text { Szczepy } \\
\text { Strains }\end{array}$} & \multicolumn{3}{c}{$\begin{array}{l}\text { Wielkość produktów RT-PCR [kpz] } \\
\text { Size of the RT-PCR products [kbp] }\end{array}$} \\
\cline { 2 - 4 } & PVY c3/f & PVY 3+/- & CP2+/- \\
\hline PVY $^{\mathrm{N}}$ & 0,44 & 1,11 & - \\
\hline $\begin{array}{l}\text { PVY } \\
\text { niezrekombinowany } \\
\mathrm{PVY}^{\mathrm{NTN}} \text { nonrecombinant }\end{array}$ & 0,44 & 1,11 & - \\
\hline $\begin{array}{l}\mathrm{PVY}^{\mathrm{NTN}} \text { zrekombinowany } \\
\mathrm{PVY}^{\mathrm{NTN}} \text { recombinant }\end{array}$ & 0,44 & - & - \\
\hline $\mathrm{PVY}^{\mathrm{O}}$ & 0,66 & - & 0,53 \\
\hline $\mathrm{PVY}^{\mathrm{N}} \mathrm{Wi}\left(\mathrm{PVY}^{\mathrm{N}} \mathrm{Wi}-\mathrm{P}\right)$ & - & - & 0,53 \\
\hline $\mathrm{PVY}^{\mathrm{N}} \mathrm{Wi}\left(\mathrm{PVY}^{\mathrm{N}} \mathrm{N} 242\right)$ & 0,44 & - & 0,53 \\
\hline $\mathrm{PVY}^{\mathrm{C}}$ & 0,66 & - & - \\
\hline
\end{tabular}

\section{Wyniki i dyskusja / Results and discussion}

Spośród 176 zebranych prób, w 147 (69 w roku 2012 oraz 78 w roku 2013) potwierdzono obecność wirusa. Podobne nasilenie występowania PVY na pomidorze szklarniowym obserwowano w latach 2002 oraz 2008 (Pospieszny 2003; Pospieszny i wsp. 2009). Wydaje się, że na takie zmiany $\mathrm{w}$ porażaniu roślin przez wirusa naprzemienne nasilanie i ograniczanie jego występowania, mogą mieć wpływ zmienne warunki klimatyczne. Ciepła, długa wiosna oraz ciepłe lato są korzystne dla rozwoju mszyc, które w sprzyjających warunkach mogą efektywniej przenosić wirusa, co skutkuje jego nasilonym występowaniem. Po przeniesieniu pozyskanych izolatów na rośliny testowe obserwowano objawy chorobowe charakterystyczne dla PVY. W przypadku 3 roślin testowych (D. inoxia, S. lycopersicum cv. Moneymaker oraz S. melongena) symptomy chorobowe różniły się zależnie od szczepu wirusa. Wszystkie testowane odmiany tytoniu wykazywały systemiczne objawy chorobowe, specyficzne dla infekcji PVY (tab. 2). W początkowym etapie porażenia wirusem obserwowane były przejaśnienia wzdłuż nerwów, przechodzące kolejno w silne deformacje blaszki liściowej. Odnotowywano również zamieranie starszych porażonych liści, a także zahamowanie wzrostu i karłowacenie roślin. Wyraźne objawy chorobowe rejestrowano również w przypadku roślin $D$. inoxia, $S$. melongena oraz wszystkich odmian pomidora (tab. 2). Na roślinach D. inoxia obserwowane objawy chorobowe w postaci przebarwień i deformacji blaszek liściowych występowały jedynie w przypadku porażenia przez izolaty należące do trzech szczepów wirusa: $\mathrm{PVY}^{\mathrm{N}} \mathrm{Wi}-\mathrm{P}, \mathrm{PVY}^{\mathrm{N}} \mathrm{N} 242$ oraz $\mathrm{PVY}^{\mathrm{NTN}}$. W przypadku porażenia roślin D. inoxia przez izolaty należące do szczepu PVY ${ }^{\mathrm{O}}$ infekcja była bezobjawowa. Odwrotną sytuację obserwowano dla roślin oberżyny. Jedynie w wyniku porażenia przez izolaty należące do szczepu $\mathrm{PVY}^{\mathrm{O}}$ widoczne były objawy chorobowe w postaci deformacji blaszek liściowych oraz zahamo- 
Tabela 2. Objawy na roślinach testowych powodowane przez różne szczepy PVY

Table 2. Symptoms on tested plants caused by different strains of PVY

\begin{tabular}{|c|c|c|c|c|}
\hline \multirow{2}{*}{ Rośliny - Plants } & \multicolumn{4}{|c|}{ Szczepy - Strains } \\
\hline & $\mathrm{PVY}^{\mathrm{N}} \mathrm{Wi}-\mathrm{P}$ & $\mathrm{PVY}^{\mathrm{N}} \mathrm{N} 242$ & $\mathrm{PVY}^{\mathrm{NTN}}$ & $\mathrm{PVY}^{\mathrm{O}}$ \\
\hline Nicotiana benthamiana & $\mathrm{d}$ & $\mathrm{d}$ & $\mathrm{d}$ & $\mathrm{d}$ \\
\hline N. occidentalis & $\mathrm{d}, \mathrm{z}, \mathrm{zm}$ & $\mathrm{d}, \mathrm{z}, \mathrm{zm}$ & $\mathrm{d}, \mathrm{z}, \mathrm{zm}$ & $\mathrm{d}, \mathrm{z}, \mathrm{zm}$ \\
\hline N. tabacum cv. Samsun & pn, d, zm, z & pn, d, zm, z & pn, d, zm, z & pn, d, zm, z \\
\hline N. tabacum cv. Xanthi & pn, d, zm, z & pn, d, zm, z & pn, d, zm, z & pn, d, zm, z \\
\hline N. tabacum cv. White Burley & pn, d, zm, z & pn, d, zm, z & pn, d, zm, z & pn, d, zm, z \\
\hline Physalis floridana & - & - & - & - \\
\hline Datura inoxia & $\mathrm{d}, \mathrm{p}$ & $\mathrm{d}, \mathrm{p}$ & $\mathrm{d}, \mathrm{p}$ & (s) \\
\hline Chenopodium quinoa & - & - & - & - \\
\hline Solanum lycopersicum cv. Beta Lux & $\mathrm{d}$ & $\mathrm{d}$ & $\mathrm{d}$ & $\mathrm{d}$ \\
\hline S. lycopersicum cv. Grace & $\mathrm{d}$ & $\mathrm{d}$ & $\mathrm{d}$ & $\mathrm{d}$ \\
\hline S. lycopersicum cv. Moneymaker & $\mathrm{d}$ & $\mathrm{d}$ & $\mathrm{d}, \mathrm{n}$ & $\mathrm{d}$ \\
\hline S. lycopersicum cv. Malinowy Ożarowski & $\mathrm{d}$ & $\mathrm{d}$ & $\mathrm{d}$ & $\mathrm{d}$ \\
\hline Capsicum annuum & (s) & $(\mathrm{s})$ & (s) & $(\mathrm{s})$ \\
\hline S. melongena & (s) & (s) & (s) & $\mathrm{z}, \mathrm{d}$ \\
\hline
\end{tabular}

d - deformacje, z - zahamowanie wzrostu, skarłowacenie roślin, zm - zamieranie liści, pn - przejaśnienia nerwów, (s) - infekcja utajona, n - nekrozy, $\mathrm{p}$ - przebarwienia blaszek, ,-," - brak infekcji

$\mathrm{d}$ - deformation, $\mathrm{z}$ - stunting of the plants, $\mathrm{zm}$ - plants death, $\mathrm{pn}$ - veins clearing, $\mathrm{s}-$ symptomless infection, $\mathrm{n}-\mathrm{nec}$ blades, ,-" - no infection

wania wzrostu. W wyniku infekcji wirusem wszystkich testowanych odmian pomidora pojawiały się deformacje blaszki liściowej, zwijanie brzegów blaszki liściowej oraz zahamowanie wzrostu (tab. 2). Ponadto, na roślinach pomidora odmiany Moneymaker, po około 2 tygodniach od inokulacji obserwowano nekrotyczne plamy na blaszkach liściowych, powodowane przez izolaty zaklasyfikowane później do szczepu PVY ${ }^{\mathrm{NTN}}$. Izolaty należące do tego szczepu uważane są za główne czynniki wywołujące PTNRD (Tuber Necrotic Ringspot Disease) na ziemniaku (Chikh Ali i wsp. 2007).

Obecność wirusa w roślinach testowych potwierdzono za pomocą testu immunoenzymatycznego ELISA z komercyjną surowicą specyficzną dla PVY, a także wykorzystując transmisyjny mikroskop elektronowy. Przeprowadzony test ELISA pozwolił na potwierdzenie obecności wirusa $\mathrm{W}$ materiale biologicznym pochodzącym $\mathrm{z}$ roślin testowych, zarówno w roślinach z wyraźnymi objawami chorobowymi, jak i w roślinach, u których nie obserwowano objawów takich, jak: C. annuum, S. melongena oraz D. inoxia (tab. 2). Rośliny testowe, na których wystąpiły objawy chorobowe typowe dla PVY sprawdzano pod kątem obecności cząstek nitkowatych o długości $730 \mathrm{~nm}$, typowych dla wirusów z rodzaju Potyvirus. We wszystkich przypadkach w soku roślinnym potwierdzono obecność infekcji wirusowej (rys. 1A, B).

$\mathrm{Na}$ podstawie wielkości produktów uzyskanych w wyniku RT-PCR (rys. 2) wszystkie izolaty przyporządkowano do konkretnych szczepów (tab. 1). Wykazano, że spośród 147 wstępnie zweryfikowanych izolatów 76 należy do szczepu PVY ${ }^{\mathrm{N}}$ Wi-P, 30 do szczepu PVY ${ }^{\mathrm{N}} \mathrm{N} 242$, 27 do szczepu PVY ${ }^{\mathrm{NTN}}$, natomiast 14 do szczepu $\mathrm{PVY}^{\mathrm{O}}$.
Dodatkowo, w niektórych próbach obserwowano obecność infekcji mieszanych.

Dotychczas na pomidorze w Polsce obserwowane były jedynie izolaty wirusa należące do szczepu PVY ${ }^{\mathrm{N}} \mathrm{Wi}-\mathrm{P}$ (Pospieszny i wsp. 2009). W latach 2012-2013 stwierdzono występowanie różnych szczepów wirusa $\left(\mathrm{PVY}^{\mathrm{N}} \mathrm{Wi}\right.$ $\mathrm{P}, \mathrm{PVY}^{\mathrm{N}} \mathrm{N} 242, \mathrm{PVY}^{\mathrm{NTN}}$ i PVY ${ }^{\mathrm{O}}$ ), stąd struktura populacji wirusa pochodzącego z pomidora bardziej przypomina tę występującą na ziemniaku. Jak wynika $\mathrm{z}$ przeprowadzonych analiz zdecydowaną większość zidentyfikowanych izolatów w Polsce na pomidorze stanowią te należące do szczepu $\mathrm{PVY}^{\mathrm{N}} \mathrm{Wi}-\mathrm{P}$, podobnie jak ma to miejsce w roślinach ziemniaka (Golnik i wsp. 2007), natomiast najmniej jest izolatów należących do szczepu PVY ${ }^{\mathrm{O}}$.
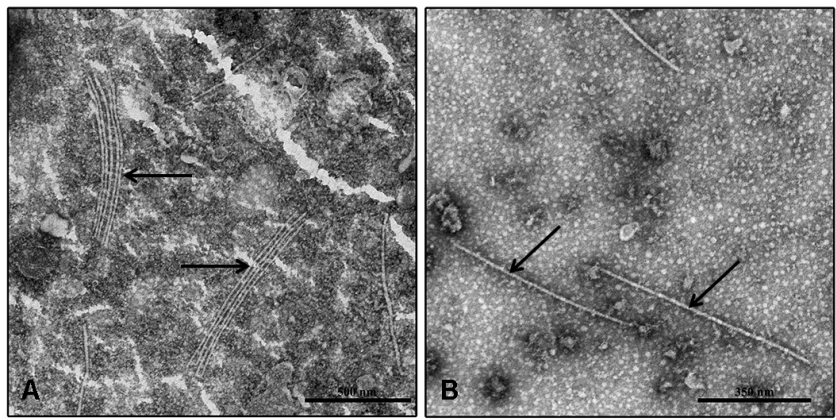

Rys. 1A, B. Nitkowate cząstki wirusa [strzałki] w soku pochodzącym z porażonych roślin

Fig. 1A, B. Filamentous virus particles [arrows] in sap from the infected plants 


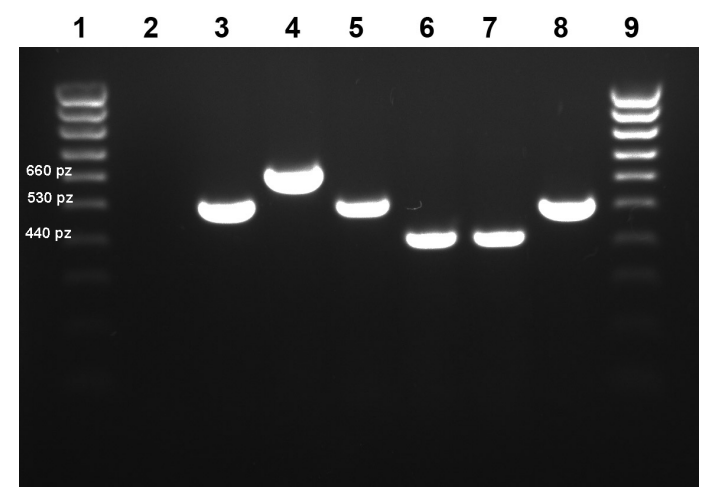

Rys. 2. Rozdział elektroforetyczne produktów reakcji RT-PCR Fig. 2. Electrophoretic separation of RT-PCR products 1, 9 - marker HypperLader IV (Bioline); 2 - kontrola negatywna; 3, 4 $\mathrm{PVY}^{\mathrm{O}} ; 5,6-\mathrm{PVY}^{\mathrm{N}} \mathrm{N} 242 ; 7-\mathrm{PVY}^{\mathrm{NTN}} ; 8$ - $\mathrm{PVY}^{\mathrm{N}} \mathrm{Wi}-\mathrm{P} ; 4,6,7$ - startery PVY c3/f; 3, 6, 8 - starter 2+/1-

1, 9 - HypperLadder IV (Bioline); 2 - negative control; 3, 4 - PVY 5, $6-\mathrm{PVY}^{\mathrm{N}} \mathrm{N} 242 ; 7-\mathrm{PVY}^{\mathrm{NTN}} ; 8$ - $\mathrm{PVY}^{\mathrm{N}} \mathrm{Wi}-\mathrm{P} ; 4,6,7$ - PVY c3/f primers; $3,6,8-\mathrm{CP} 2+/ 1-$ primer

Z tego względu można wnioskować, że źródłem infekcji jest ziemniak, którego bulwy są w około $40 \%$ porażone przez PVY. Ponadto, na zdecydowany wzrost porażenia roślin pomidora przez tego wirusa może mieć wpływ zmiana w strukturze populacji mszyc, a także wcześniejsze rozpoczęcie wiosennej migracji przez ich „nieziemniaczane” gatunki (Kostiw i Robak 2008; Pospieszny i wsp. 2009). Z uwagi na wzrost znaczenia mszyc nieziemniaczanych wydaje się, że zagrożenie wirusem upraw pomidora będzie wzrastało.

\section{Wnioski / Conclusions}

1. W latach 2012 i 2013 zaobserwowano liczne występowanie wirusa $\mathrm{Y}$ ziemniaka na roślinach pomidora szklarniowego i gruntowego w różnych regionach Polski.

2. Znaczącej zmianie uległa struktura populacji tego wirusa na pomidorze. Stwierdzono obecność czterech różnych szczepów wirusa: $\mathrm{PVY}^{\mathrm{N}} \mathrm{Wi}-\mathrm{P}, \mathrm{PVY}^{\mathrm{N}} \mathrm{N} 242$, $\mathrm{PVY}^{\mathrm{NTN}}$ oraz $\mathrm{PVY}^{\mathrm{O}}$, w stosunku odpowiednio 52, 20, 18 i $10 \%$, co odpowiada strukturze populacji wirusa występującej na ziemniaku.

Projekt został sfinansowany ze środków Narodowego Centrum Nauki przyznanych na podstawie decyzji numer DEC-2012/07/N/NZ9/01751.

\section{Literatura / References}

Aramburu J., Galipienso L., Matas M. 2006. Characterization of potato virus Y isolates from crops in northeast Spain. Eur. J. Plant Pathol. 115: 247-258.

Borodynko N., Hasiów-Jaroszewska B. 2012. Wirus Y ziemniaka na pomidorze. Hasło Ogrodnicze 10: 84-86.

Beczner L., Horváth J., Romhányi I., Förster H. 1984. Studies on the etiology of tuber necrotic ringspot disease in potato. Potato Res. 27: 339-352.

Chikh Ali M., Maoka T., Natsuaki K.T. 2007. A point mutation changes the serotype of a Potato virus Y isolate; genomic determination of the serotype of PVY strains. Virus Genes 35 (2): 359-367.

Chrzanowska M. 1991. New isolates of the necrotic strain of Potato virus Y (PVYN) found recently in Poland. Potato Res. 34 (2): $179-182$.

Clark M.F., Adams A.N. 1977. Characteristics of the microplate method of enzyme-linked immunosorbent assay for the detection of plant viruses. J. Gen. Virol. 34: 475-483.

Cuevas J.M., Delaunay A., Visser J.C., Bellstedt D.U., Jacquot E., Elena S.F. 2012. Phylogeography and molecular evolution of Potato virus Y. PLoS ONE 7 (5): e37853.doi:10.1371/journal.pone.0037853

Dougherty W.G., Carrington J.C. 1988. Expression and function of potyviral gene products. Ann. Rev. Phytopathol. 26: 123-143.

Glais L., Tribodet M., Kerlan C. 2002. Genomic variability in Potato potyvirus Y (PVY): evidence that PVY ${ }^{\mathrm{N}} \mathrm{W}$ and $\mathrm{PVY} \mathrm{Y}^{\mathrm{NTN}}$ variants are single to multiple recombinants between $\mathrm{PVY}^{\mathrm{O}}$ and $\mathrm{PVY}^{\mathrm{N}}$ isolates. Arch. Virol. 147 (2): 363-378.

Golnik K., Syller J., Chrzanowska M., Sztangret-Wiśniewska J. 2007. Metody identyfikacji szczepów wirusa Y ziemniaka. [Methods for recognition Potato virus Y (PVY) strains]. Prog. Plant Prot./Post. Ochr. Roślin 47 (2): 94-96.

Hall J.S., Adams B., Parsons T.J., French R., Lane L.C., Jensen S.G. 1998. Molecular cloning, sequencing, and phylogenetic relationships of a new potyvirus: sugarcane streak mosaic virus, and a reevaluation of the classification of the potyviridae. Mol. Phylogenet. Evol. 10: 323-332.

Harrington R., Katis N., Gibson R.W. 1986. Field assessment of the relative importance of different aphid species in the transmission of potato virus Y. Potato Res. 29: 67-76.

Kostiw M., Robak B. 2008. Skład gatunkowy, termin migracji i dynamika liczebności mszyc „nieziemniaczanych” w uprawie ziemniaka w różnych rejonach kraju. [Species composition, migration period and dynamics of number of non potato colonizing aphids in different regions of Poland]. Prog. Plant Prot./Post. Ochr. Roślin 48 (3): 881-888.

Loebenstein G., Lecoq H. 2012. Viruses and virus diseases of vegetables in the Mediterranean basin. Adv. Virus Res. 84: $212-216$.

Piron P.G.M. 1986. New aphid vectors of Potato virus YYN. Netherlands J. Plant Pathol. 92: 223-229.

Pospieszny H. 2003. Nasilone występowanie chorób wirusowych pomidora szklarniowego w Wielkopolsce, w roku 2002. [Increased occurrence of vidal diseases on greenhouse tomatoes in Wielkopolska in 2002]. Prog. Plant Prot./Post. Ochr. Roślin 43 (1): $321-324$.

Pospieszny H., Borodynko N., Hasiów-Jaroszewska B. 2009. Wirus Y ziemniaka (Potato virus Y, PVY) na pomidorze szklarniowym. [Potato virus Y (PVY) on the greenhouse tomato]. Prog. Plant Prot./Post. Ochr. Roślin 49 (3): 1327-1330.

Rigotti S., Gugerli P. 2007. Rapid identification of potato virus Y strain by one-step RT-PCR. J. Virol. Methods 140: 90-94.

Tribodet M., Glais L., Kerlan C., Jacquot E. 2005. Characterization of Potato virus Y (PVY) molecular determinants involved in the vein necrosis symptom induced by PVYN isolates in infected Nicotiana tabacum cv. Xanthi. J. Gen. Virol. 86: 2101-2105. 